\title{
Comparison of the European Union, Spain and Switzerland Gender Inequality In Unemployment by Education Attainment
}

\author{
Marina Fad'oš and Mária Bohdalová \\ Comenius University in Bratislava, Faculty of Management, Bratislava, Slovakia
}

Correspondence should be addressed to: Robert Kinanga; rongeta@yahoo.com

Received date: 3 March 2017; Accepted date: 20 June 2017; Published date: 24 November 2017

Academic Editor: Sabina Irimie

Copyright (C) 2017. Marina Fad'oš and Mária Bohdalová .Distributed under Creative Commons CC-BY 4.0

\begin{abstract}
Gender inequality can differ by education attainment of the unemployed. Discrepancy between education attainment of the unemployed changed too. Nowadays, the ratio between primary and tertiary education in unemployment is higher than ever before in Spain and the European Union. Inequality among unemployed people in Switzerland couldn't be proven. Gender inequality in unemployment by education attainment and convergence of education attainment of the unemployed in the European Union, Spain and Switzerland was examined in this paper. Analysis has been carried out using unit-root test which allows for one structural break. With this method, we have examined the validity of hysteresis in unemployment gender inequality by education attainment and discrepancy between education attainment of the unemployed, analysed persistence of inequality and influence of the random shocks on them. Discrepancies between education attainment of the unemployed were compared by genders with Paired samples $t$-test. Women are still at a disadvantage compared to men, random economic shocks have low or non-existent impact on the gender gap and education attainment discrepancies in analysed countries and the European Union, and their impact has been just temporary. Education attainment discrepancy increased among the unemployed in Spain and the European Union, this could be the consequence of companies changed preference of employee education. They preferred employees with higher education attainment before those with lower education attainment.
\end{abstract}

Keywords: unemployment, gender inequality, unit-root test, education

Cite this Article as: Marina Fad'oš and Mária Bohdalová (2017)," Comparison of the European Union, Spain and Switzerland Gender Inequality In Unemployment by Education Attainment" Journal of Human Resources Management Research, Vol. 2017 (2017), Article ID 117303, DOI: 10.5171/2017. 117303 


\section{Introduction}

Inequality among genders during unemployment was analysed by many academic papers, but there is still necessity to analyse how contemporary economic disturbances in Europe influence it. In our paper, we consider two countries: Switzerland and Spain and the European Union area. Switzerland has been chosen to represent countries with low and stable unemployment rates, Spain to represent countries with high and turbulent unemployment rates and the European Union area which represents countries with average and steady unemployment rates. We examine the dynamics and persistence of unemployment gender inequality and educational attainment of the unemployed for a panel of two European countries and the European Union area over the period from 1996 to 2015 using panel unit root test with one break-point. This study will give us an inside into the importance of education. In addition, this paper analyses the influence of random shocks. We believe the presented study is important from a policy point of view.

The paper is organized as follows. The next section provides literature review of unemployment researching during the past years; the next section outlines data and used methodology. Section 3 presents reports of the empirical results. The last section gives our conclusion.

\section{Literature Review}

With higher educational attainment of the workforce, unemployment rate was lower. Employers prefer highly skilled employees before low skilled employees, since they could achieve a higher outcome and are more productive than low skilled employees (Muntigl, et al., 2000). The European Union is, in the Europe 2020 Strategy, oriented on the preparation of people for the labour market, which is very exigent, by building their skills and rising education level between people and by promoting lifelong learning. Through building skills of the workforce, they will be prepared for rapidly changing market and the long-term unemployment will be decreased. It is expected that by $2020,35 \%$ of jobs will require highly-skilled employees, while in 2011 only $26 \%$ of the workforce had higher education. Europe also needs more researchers, so it could become more research-intensive, which would result in better forecasts of the future situation in economies. Education, research and business should be linked together and with their combined cooperation and knowledge sharing, development and growth of the economies would be faster. To rise education level in the European Union, the European Commission also promotes youth mobility, so experience and knowledge could be shared between EU countries and promising alliances could be made (European Commission, 2011).

High unemployment of low-skilled workers in Spain was the consequence of ladder effect (employees with higher education occupied job-positions suitable for lowskilled employees). Workers with higher education that preferred low-skill jobs were mostly young people which needed a first job so they could gain experience and on the-job training. Firms preferred this group of employees because it gave them access to highly skilled workforce, which increased companies' productivity without further training (Fournier and Mercier, 2009).

According to Strahm (2013), low unemployment in Switzerland is due to vocational dual-track and professional education as well as training system. According to the survey, which was conducted by the Swiss Federal Statistical Office, it was confirmed that industry needed more qualified workers because of whom those with poor education were left without a job. Switzerland is known as a country whose industry is based on quality, which is yet another reason why unemployment of low-qualified workers was increasing. 
Since women entered the labour market, they were considered less valuable than men. They were also paid less than men and had fewer rights than men (Van der Vleuten, 2013). Gokulsing and TandrayenRagoobur (2014) discovered that not even better performance at school of females helps them to be preferred at the labour market before males with lower performance at school. Also, they explained that high unemployment of females could be explained by wrong vocational attainment of women, since they have usually chosen professions with which labour market was already saturated. The importance of education attainment and labour market demand was also explained by Chang and Su (2014). They have proven that higher education does not necessarily lead to lower unemployment since in the last years expansion of high school education was not supported with labour demand expansion which could employ them. Riddel and Song (2011) discovered that unemployed people with higher education were re-employed faster than people with lower education. Theodossiou and Zangelidis (2009) found out that the most vulnerable were low educated women whose probability of transition to non-employment was the highest.

Inequality among genders in unemployment was analysed by many research studies during the last years. According to Queneau and Sen (2007), gender inequality in unemployment is not persistent and is disappearing. Bakas and Papapetrou (2014) claimed that gender inequality is still persistent. Peiró, BelaireFranch and Gonzalo (2012) claimed that cyclical disturbances had considerable influence on unemployment, especially on male unemployment. Koutentakis (2015) linked unemployment gender inequality to gender inequality in separation rates and claimed that gender differences in separation rates are the main reasons for unemployment gender inequality. Azmat, Güell and Manning (2004) claimed that gender inequality in unemployment can be explained by differences in characteristics such as age, education, marital status and the presence of kids in the household.

In this paper, we would examine gender inequality in unemployment by educational attainment and discrepancy between educational attainment in unemployment with the use of panel unit root test with break-point, in Spain, Switzerland and the European Union. Variation of the method we used to examine gender inequality by education was previously introduced in the analysis of unemployment hysteresis also in papers of Belloc and Tilli (2013), Gozgor (2013), Fallahi and Rodriguez (2015), Garcia-Cintado, Romero-Avila and Usabiaga (2015), Venetis and Salamaliki (2015) and Marques, Lima and Troster (2017).

\section{Data and Methodology}

Annual unemployment rate data of people aged from 15 to 74 years, by educational attainment and gender, over the sample period 1996-2015 of Spain, Switzerland and the European Union, on which this analysis was based, were obtained from Eurostat database (2016). Series were computed as a ratio of one unemployment group to another, denoted as $u^{R}=a / b$. If the value of the $u^{R}$ was higher than one, unemployment of characteristic $a$ was superior than unemployment of characteristic $b$. Variables $a$ and $b$ stand for unemployment rate by characteristics listed in the table below.

Table 1: Table of Series Definitions

\begin{tabular}{|l|c|l|l|}
\hline & Series & \multicolumn{1}{c|}{$a$} & \multicolumn{1}{c|}{$b$} \\
\hline 1. & $\mathrm{u}^{\mathrm{R}}(\mathrm{PS} \mid \mathrm{T})$ & Primary education Total & Secondary education Total \\
\hline 2. & $\mathrm{u}^{\mathrm{R}}(\mathrm{PT} \mid \mathrm{T})$ & Primary education Total & Tertiary education Total \\
\hline 3. & $\mathrm{u}^{\mathrm{R}}(\mathrm{ST} \mid \mathrm{T})$ & Secondary education Total & Tertiary education Total \\
\hline 4. & $\mathrm{u}^{\mathrm{R}}(\mathrm{PS} \mid \mathrm{F})$ & Primary education Female & Secondary education Female \\
\hline
\end{tabular}

Marina Fad'oš and Mária Bohdalová (2017), Journal of Human Resources Management Research, DOI: 10.5171/2017.117303 


\begin{tabular}{|l|l|l|l|}
\hline 5. & $\mathrm{u}^{\mathrm{R}}(\mathrm{PT} \mid \mathrm{F})$ & Primary education Female & Tertiary education Female \\
\hline 6. & $\mathrm{u}^{\mathrm{R}}(\mathrm{ST} \mid \mathrm{F})$ & Secondary education Female & Tertiary education Female \\
\hline 7. & $\mathrm{u}^{\mathrm{R}}(\mathrm{PS} \mid \mathrm{M})$ & Primary education Male & Secondary education Male \\
\hline 8. & $\mathrm{u}^{\mathrm{R}}(\mathrm{PT} \mid \mathrm{M})$ & Primary education Male & Tertiary education Male \\
\hline 9. & $\mathrm{u}^{\mathrm{R}}(\mathrm{ST} \mid \mathrm{M})$ & Secondary education Male & Tertiary education Male \\
\hline 10. & $\mathrm{u}^{\mathrm{R}}(\mathrm{FM} \mid \mathrm{P})$ & Primary education Female & Primary education Male \\
\hline 11. & $\mathrm{u}^{\mathrm{R}}(\mathrm{FM} \mid \mathrm{S})$ & Secondary education Female & Secondary education Male \\
\hline 12. & $\mathrm{u}^{\mathrm{R}}(\mathrm{FM} \mid \mathrm{T})$ & Tertiary education Female & Tertiary education Male \\
\hline
\end{tabular}

*Primary education stands for education levels 0 -2, secondary education for education levels 3-4 and tertiary education for education levels 5-8.

** Series 1 to 9 represent series of discrepancies between education attainment in unemployment (series 1 to 3 of total unemployed people, series 4 to 6 of females and series 7 to 9 of males). Series 10 to 12 represent unemployment gender inequality series by educational attainment.

Source: Own processing

\section{Unit root test with break-point}

Unit root test with break-point should reveal how random economic disturbances impact computed unemployment and education gap series. We study if random economic disturbances have temporary or permanent influence or if they cause a trend in the evolution of unemployment and education gap. We will analyse trend-stationarity in unemployment rate and education gap. Trend-stationarity means that time series evolve around a deterministic trend with transitory shocks (Queneau and Sen, 2009b).

Hypotheses of unit root test are (Ng and Perron, 1995):

$H_{0}$ : If $\alpha=0$, serie has unit root, it is not stationary and excludes any structural breaks

$H_{1}$ : If $\alpha<0$, serie has no unit root, it is stationary with one break at an unkown point in time

Stationarity was tested with Perron's (1988) modified $t$-statistic,

$$
Z_{t}=\left(\frac{\hat{\sigma}^{2}}{\hat{\lambda}^{2}}\right)^{1 / 2} \cdot t_{\alpha}-\frac{1}{2}\left(\frac{\hat{\lambda}^{2}-\hat{\sigma}^{2}}{\hat{\lambda}^{2}}\right) \cdot\left(\frac{T \cdot S E(\hat{\alpha})}{\hat{\sigma}^{2}}\right)
$$

In Perron's modified $t$-statistic, $\hat{\sigma}^{2}$ and $\hat{\lambda}^{2}$ are consistent estimates of the variance parameters $\sigma^{2}=\lim _{T \rightarrow \infty} T^{-1} \sum_{t=1}^{T} E\left[u_{t}^{2}\right] \quad$ and $\lambda^{2}=\lim _{T \rightarrow \infty} \sum_{t=1}^{T} E\left[T^{-1} S_{T}^{2}\right] \quad$ where $S_{T}=\sum_{t-1}^{T} u_{t}$ and $u_{t}=y_{t}-y_{t-1}, S E(\hat{\alpha})$ is coefficient standard error, $t_{\alpha}$ is $t$-ratio of $\alpha$.

Unit root test with break-point has been performed as it was described by Perron (1989) for the regression:

$$
y_{t}=\mu+\theta D U\left(T_{b}\right)_{t}+\beta t+\gamma D T\left(T_{b}\right)_{t}+\delta D\left(T_{b}\right)_{t}+\alpha y_{t-1}+\sum_{i=1}^{k^{*}} c_{i} \Delta y_{t-1}+e_{t}
$$

where $y_{t}$ represents one of the series of unemployment rate gap, one of the listed above. $D U_{t}$ stands for intercept-break dummy, and it is equal to one if $t>T_{b}, 0$ otherwise. $D T_{t}$ stands for slope-break dummy and equals one if $t=T_{b}$ and $t-T_{b}+1$ if $t>T_{b}$, zero otherwise. $D_{t}$ stands for dummy variable which equals one for $t=T_{b}$ and zero otherwise. $T_{b}\left(1<T_{b}<t\right)$ stands for break-date. Only one break-date is allowed in this test. $k$ regressors in $\left\{\Delta y_{t-j}\right\}_{j=1}^{k^{*}}$ stand for additional correlation in the time series according to Queneau and Sen (2009b). Lag length $k^{*}$ 
has been chosen with $t$-test described by Perron (1997). Break date $T_{b}$ has been chosen as the date that minimizes Dickey-Fuller (1979) t-statistic:

$$
t_{\widehat{\alpha}}=\frac{\hat{\alpha}}{S E(\hat{\alpha})}
$$

\section{Persistence of Gender Inequality}

Persistence has been measured with a half-life estimator with which was measured how much time is needed so that the shock decays to half of its initial value. It is defined according to Queneau and Sen (2009a) as:

$$
H L_{\rho}=\frac{\log (0.5)}{\log (\rho)}
$$

In this equation, $=\hat{\alpha}+1$, which comes from Dickey-Fuller regression $\Delta y_{t}=\hat{\alpha} y_{t-1}+\hat{\beta} t+\hat{\mu}+$ $\sum_{j=1}^{k^{*}} \hat{c}_{j} \Delta y_{t-j}+\hat{e}_{t}$ which can be rewritten as $y_{t}-y_{t-1}=(\rho-1) y_{t-1}+\hat{\beta} t+\hat{\mu}+\sum_{j=1}^{k^{*}} \hat{c}_{j} \Delta y_{t-j}+$ $\hat{e}_{t}$.

\section{Comparison of Series}

Gaps between education attainments in unemployment by genders were compared with Paired Samples $t$-Test. Tested hypotheses were:

$H_{0}: \mu_{1}=\mu_{2}$ (Mean gaps of education attainment in unemployment of women were equal as mean gaps of education attainment in unemployment of men)

$H_{1}: \mu_{1} \neq \mu_{2}$ (Mean gaps of education attainment in unemployment of women were not equal as mean gaps of education attainment in unemployment of men)

If the -value $<0.05$, we would reject the null hypotheses and conclude that means of education gaps of genders in unemployment were not equal.

Correlation between series was tested with Pearson correlation coefficient for the hypotheses:

$H_{0}$ : Correlation between series doesn't exist

$H_{1}$ : Correlation between series exists

If the $p$-value $<0.05$, we would reject the null hypotheses and conclude that correlation between series exist.

\section{Representation of data}

The highest gap among education attainment in unemployment was between primary and tertiary education. In the European Union and Spain, people with primary educational attainment were averagely 2.5 times more unemployed than people with tertiary education. Males with primary educational attainment were 3.15 times more unemployed than males with tertiary education, while this difference was lower among women (women with primary educational attainment were 2.11 more unemployed that women with tertiary educational attainment). Highest gender inequality in unemployment was among those with tertiary education in the European Union and Switzerland, while in Spain it was among those with secondary education. 
Table 2: Descriptive Statistics

\begin{tabular}{|c|c|c|c|c|c|c|}
\hline & & $\mathbf{N}$ & Minimum & Maximum & Mean & $\begin{array}{c}\text { Std. } \\
\text { Deviation }\end{array}$ \\
\hline \multirow[t]{12}{*}{$\overline{\mathrm{EU}}$} & $\mathrm{u}^{\mathrm{R}}(\mathrm{PS} \mid \mathrm{T})$ & 20 & 1.17 & 2.00 & 1.5233 & .29296 \\
\hline & $\mathrm{u}^{\mathrm{R}}(\mathrm{PT} \mid \mathrm{T})$ & 20 & 1.78 & 3.11 & 2.5848 & .38114 \\
\hline & $\mathrm{u}^{\mathrm{R}}(\mathrm{ST} \mid \mathrm{T})$ & 20 & 1.37 & 2.14 & 1.7186 & .20037 \\
\hline & $\mathrm{u}^{\mathrm{R}}(\mathrm{PS} \mid \mathrm{F})$ & 20 & 1.17 & 1.92 & 1.4736 & .25363 \\
\hline & $\mathrm{u}^{\mathrm{R}}(\mathrm{PT} \mid \mathrm{F})$ & 20 & 1.80 & 2.87 & 2.4384 & .31473 \\
\hline & $\mathrm{u}^{\mathrm{R}}(\mathrm{ST} \mid \mathrm{F})$ & 20 & 1.38 & 1.98 & 1.6732 & .18296 \\
\hline & $\mathrm{u}^{\mathrm{R}}(\mathrm{PS} \mid \mathrm{M})$ & 20 & 1.20 & 2.08 & 1.5815 & .32115 \\
\hline & $\mathrm{u}^{\mathrm{R}}(\mathrm{PT} \mid \mathrm{M})$ & 20 & 2.00 & 3.40 & 2.7951 & .44286 \\
\hline & $\mathrm{u}^{\mathrm{R}}(\mathrm{ST} \mid \mathrm{M})$ & 20 & 1.46 & 2.28 & 1.7922 & .21630 \\
\hline & $\mathrm{u}^{\mathrm{R}}(\mathrm{FM} \mid \mathrm{P})$ & 20 & .96 & 1.58 & 1.1458 & .15323 \\
\hline & $\mathrm{u}^{\mathrm{R}}(\mathrm{FM} \mid \mathrm{S})$ & 20 & 1.04 & 1.66 & 1.2213 & .15189 \\
\hline & $\mathrm{u}^{\mathrm{R}}(\mathrm{FM} \mid \mathrm{T})$ & 20 & 1.11 & 1.75 & 1.3057 & .15230 \\
\hline \multirow[t]{12}{*}{ Spain } & $\mathrm{u}^{\mathrm{R}}(\mathrm{PS} \mid \mathrm{T})$ & 20 & .98 & 1.46 & 1.2371 & .17324 \\
\hline & $\mathrm{u}^{\mathrm{R}}(\mathrm{PT} \mid \mathrm{T})$ & 20 & 1.27 & 2.53 & 1.8452 & .45369 \\
\hline & $\mathrm{u}^{\mathrm{R}}(\mathrm{ST} \mid \mathrm{T})$ & 20 & 1.26 & 1.73 & 1.4722 & .17094 \\
\hline & $\mathrm{u}^{\mathrm{R}}(\mathrm{PS} \mid \mathrm{F})$ & 20 & .98 & 1.44 & 1.2476 & .15626 \\
\hline & $\mathrm{u}^{\mathrm{R}}(\mathrm{PT} \mid \mathrm{F})$ & 20 & 1.34 & 2.46 & 1.9000 & .38041 \\
\hline & $\mathrm{u}^{\mathrm{R}}(\mathrm{ST} \mid \mathrm{F})$ & 20 & 1.26 & 1.70 & 1.5103 & .13801 \\
\hline & $\mathrm{u}^{\mathrm{R}}(\mathrm{PS} \mid \mathrm{M})$ & 20 & 1.09 & 1.56 & 1.3288 & .15189 \\
\hline & $\mathrm{u}^{\mathrm{R}}(\mathrm{PT} \mid \mathrm{M})$ & 20 & 1.49 & 2.67 & 1.9865 & .48117 \\
\hline & $\mathrm{u}^{\mathrm{R}}(\mathrm{ST} \mid \mathrm{M})$ & 20 & 1.19 & 1.80 & 1.4781 & .21013 \\
\hline & $\mathrm{u}^{\mathrm{R}}(\mathrm{FM} \mid \mathrm{P})$ & 20 & 1.03 & 2.18 & 1.6183 & .44721 \\
\hline & $\mathrm{u}^{\mathrm{R}}(\mathrm{FM} \mid \mathrm{S})$ & 20 & 1.11 & 2.45 & 1.7224 & .47090 \\
\hline & $\mathrm{u}^{\mathrm{R}}(\mathrm{FM} \mid \mathrm{T})$ & 20 & 1.18 & 2.32 & 1.6596 & .40009 \\
\hline \multirow[t]{12}{*}{ Switzerland } & $\mathrm{u}^{\mathrm{R}}(\mathrm{PS} \mid \mathrm{T})$ & 20 & 1.61 & 2.35 & 1.9271 & .19557 \\
\hline & $\mathrm{u}^{\mathrm{R}}(\mathrm{PT} \mid \mathrm{T})$ & 20 & 1.62 & 3.36 & 2.6539 & .47759 \\
\hline & $\mathrm{u}^{\mathrm{R}}(\mathrm{ST} \mid \mathrm{T})$ & 20 & .69 & 1.79 & 1.3837 & .23796 \\
\hline & $\mathrm{u}^{\mathrm{R}}(\mathrm{PS} \mid \mathrm{F})$ & 20 & 1.34 & 2.30 & 1.8629 & .20903 \\
\hline & $\mathrm{u}^{\mathrm{R}}(\mathrm{PT} \mid \mathrm{F})$ & 20 & .98 & 3.19 & 2.1078 & .54583 \\
\hline & $\mathrm{u}^{\mathrm{R}}(\mathrm{ST} \mid \mathrm{F})$ & 20 & .43 & 1.67 & 1.1432 & .29854 \\
\hline & $\mathrm{u}^{\mathrm{R}}(\mathrm{PS} \mid \mathrm{M})$ & 20 & 1.39 & 3.83 & 2.0525 & .49704 \\
\hline & $\mathrm{u}^{\mathrm{R}}(\mathrm{PT} \mid \mathrm{M})$ & 20 & 2.15 & 5.75 & 3.1484 & .88406 \\
\hline & $\mathrm{u}^{\mathrm{R}}(\mathrm{ST} \mid \mathrm{M})$ & 20 & .87 & 1.92 & 1.5498 & .29638 \\
\hline & $\mathrm{u}^{\mathrm{R}}(\mathrm{FM} \mid \mathrm{P})$ & 20 & .74 & 1.30 & 1.0449 & .15616 \\
\hline & $\mathrm{u}^{\mathrm{R}}(\mathrm{FM} \mid \mathrm{S})$ & 20 & .79 & 2.42 & 1.1541 & .33884 \\
\hline & $\mathrm{u}^{\mathrm{R}}(\mathrm{FM} \mid \mathrm{T})$ & 20 & .72 & 4.00 & 1.6627 & .71656 \\
\hline
\end{tabular}

Source: Own processing

Gender inequality in unemployment by education was decreasing since 1996 in Spain and the European Union. In Switzerland, apparently inequality among genders doesn't exist among those with primary and secondary education, while it is still present among those with tertiary education on constant level with no evident

Marina Fad'oš and Mária Bohdalová (2017), Journal of Human Resources Management Research, DOI: $10.5171 / 2017.117303$ 
tendency. In the European Union, unemployment gender inequality was also the highest among those with tertiary education, while in Spain, gender inequality didn't depend on the educational level of unemployed people. The economic shock in 2008 led to equality among genders in unemployment in Spain and the European Union, but women unemployment rate was still higher than men unemployment rate except of those with primary education in the European Union, where male unemployment was higher than women unemployment rate. In Fig 1, unemployment gender inequality is presented by educational attainment of Spain, Switzerland and the European Union.
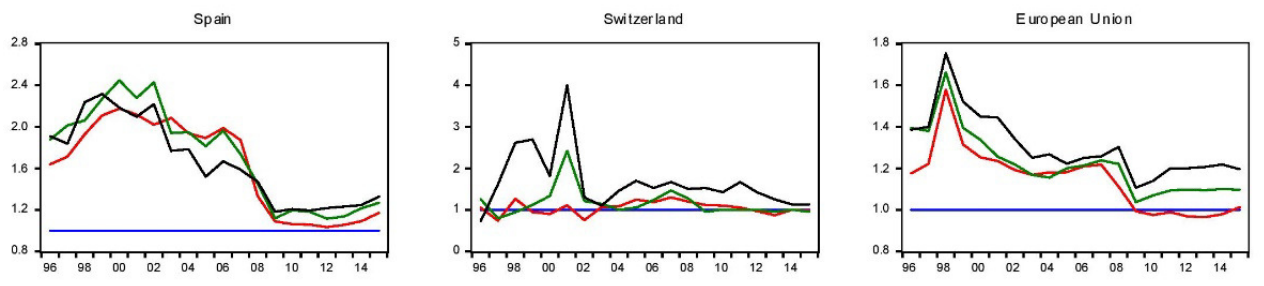

Fig. 1: Unemployment Gender Inequality by Education

Source: Own processing

Education becomes more important for employers. Proof can be found even in education of unemployed people. Highest disparity is among those with primary and tertiary education in all three territories. Among the unemployed, the majority of people had primary education. Comparing to people with tertiary education, the tendency of those with primary education was increasing in Spain and the European Union. In Switzerland, education attainment of the unemployed didn't change over time. Economic crisis had significant impact on education disparity and led to its increase in Spain and the European Union, except on secondary to tertiary ratio in the European Union, which was decreasing since 2001. We can conclude that employers prefer highly educated people, even more in time of crisis. How the ratio between education attainment in unemployment changed over time is presented in Fig 2.
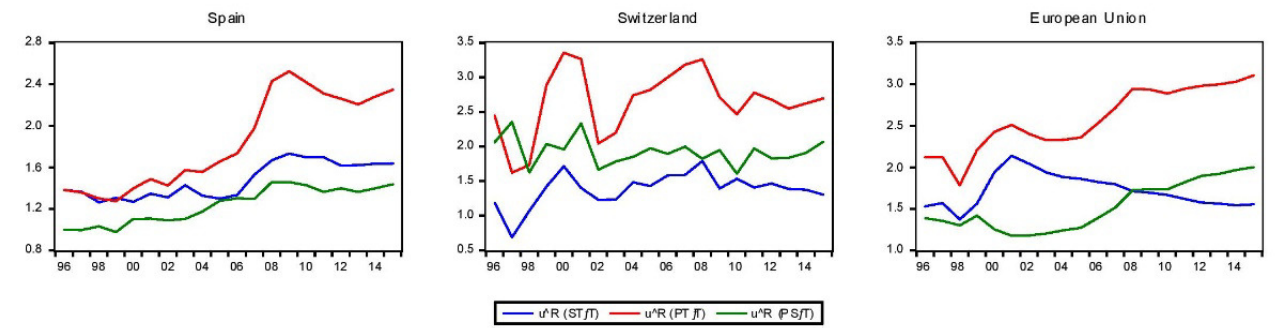

Fig. 2: Inequality between Education Attainment in Unemployment

Source: Own processing

Marina Fad'oš and Mária Bohdalová (2017), Journal of Human Resources Management Research, DOI: 10.5171/2017.117303 


\section{Comparison of Education Disparity by Gender}

Inequality between education attainment of all the unemployed was presented in Fig 2 but further analysis of influence of gender on this inequality is needed. We compared mean gaps of education attainment of women and men in unemployment, to discover if they were equal. We tested our first hypotheses and present you our results in Table 3.

Table 3: Results from Paired Samples t-test

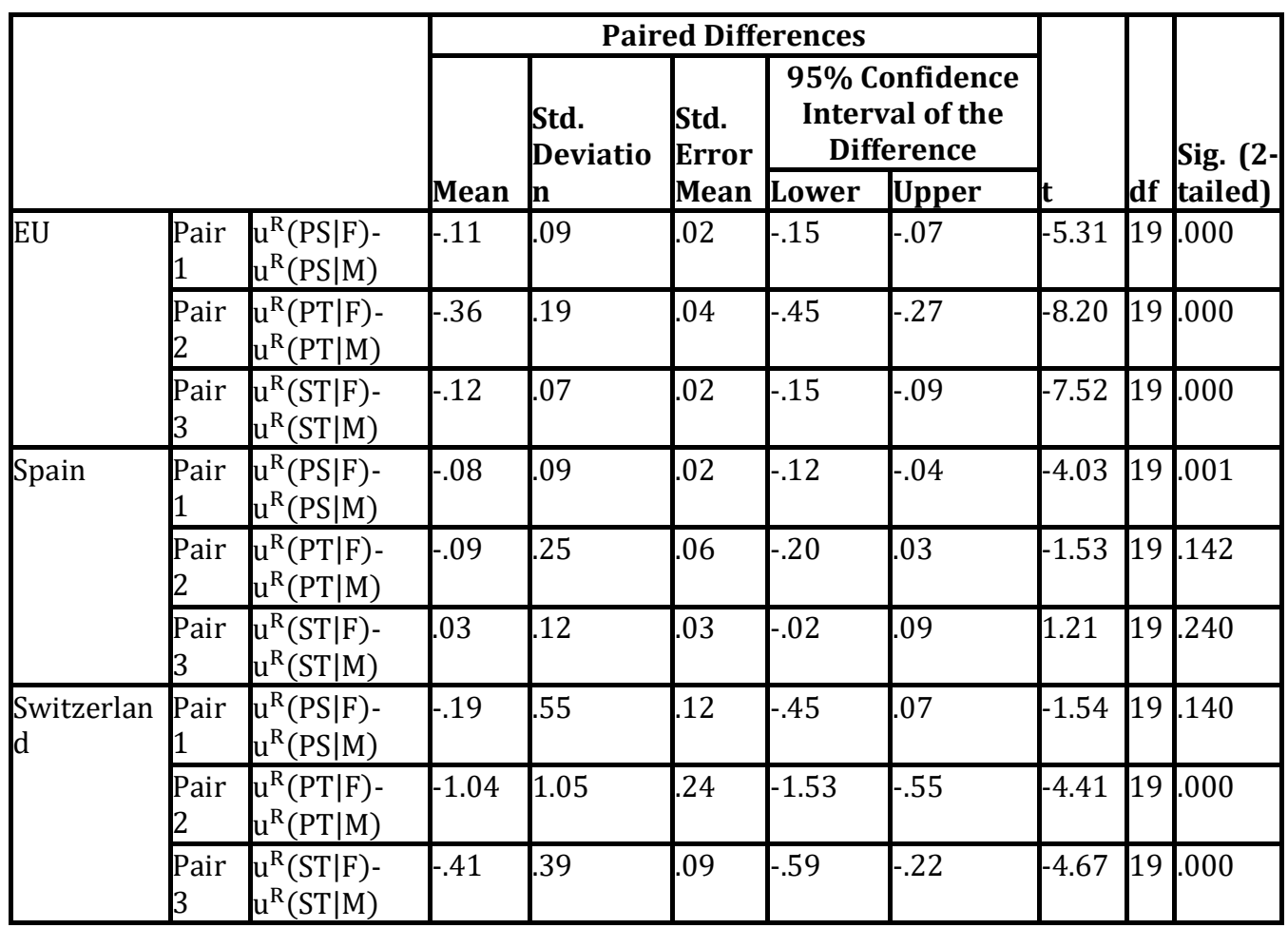

Source: Own processing

According to the results presented in Table 3 , education attainment gaps means in unemployment of genders were not equal in all series in the European Union. This would indicate that there is gender inequality in education attainment in unemployment. This is also true for two series in Switzerland concerning tertiary education and education gap in unemployment between primary and secondary education in Spain. After testing series of correlation with Pearson correlation coefficient, we have discovered that the series of the European Union and Spain were highly positively correlated while there was no correlation between the series of Switzerland. Education disparity in unemployment was lower among women in the European Union and Spain, while in Switzerland education disparity in unemployment by genders was not proven. Results of Pearson correlation are presented in 4 Table 
Table 4: Paired Samples Correlations

\begin{tabular}{|l|l|l|r|r|r|}
\hline \multicolumn{2}{|c|}{} & \multicolumn{1}{|c|}{ N } & Correlation & \multicolumn{1}{c|}{ Sig. } \\
\hline \multirow{4}{*}{ EU } & Pair 1 & $\mathrm{u}^{\mathrm{R}}(\mathrm{PS} \mid \mathrm{F}) \& \mathrm{u}^{\mathrm{R}}(\mathrm{PS} \mid \mathrm{M})$ & 20 & .977 & .000 \\
\cline { 2 - 6 } & Pair 2 & $\mathrm{u}^{\mathrm{R}}(\mathrm{PT} \mid \mathrm{F}) \& \mathrm{u}^{\mathrm{R}}(\mathrm{PT} \mid \mathrm{M})$ & 20 & .923 & .000 \\
\cline { 2 - 6 } & Pair 3 & $\mathrm{u}^{\mathrm{R}}(\mathrm{ST} \mid \mathrm{F}) \& \mathrm{u}^{\mathrm{R}}(\mathrm{ST} \mid \mathrm{M})$ & 20 & .951 & .000 \\
\hline \multirow{5}{*}{ Spain } & Pair 1 & $\mathrm{u}^{\mathrm{R}}(\mathrm{PS} \mid \mathrm{F}) \& \mathrm{u}^{\mathrm{R}}(\mathrm{PS} \mid \mathrm{M})$ & 20 & .829 & .000 \\
\cline { 2 - 6 } & Pair 2 & $\mathrm{u}^{\mathrm{R}}(\mathrm{PT} \mid \mathrm{F}) \& \mathrm{u}^{\mathrm{R}}(\mathrm{PT} \mid \mathrm{M})$ & 20 & .853 & .000 \\
\cline { 2 - 7 } & Pair 3 & $\mathrm{u}^{\mathrm{R}}(\mathrm{ST} \mid \mathrm{F}) \& \mathrm{u}^{\mathrm{R}}(\mathrm{ST} \mid \mathrm{M})$ & 20 & .847 & .000 \\
\hline \multirow{3}{*}{ Swiss } & Pair 1 & $\mathrm{u}^{\mathrm{R}}(\mathrm{PS} \mid \mathrm{F}) \& \mathrm{u}^{\mathrm{R}}(\mathrm{PS} \mid \mathrm{M})$ & 20 & .060 & .802 \\
\cline { 2 - 7 } & Pair 2 & $\mathrm{u}^{\mathrm{R}}(\mathrm{PT} \mid \mathrm{F}) \& \mathrm{u}^{\mathrm{R}}(\mathrm{PT} \mid \mathrm{M})$ & 20 & .033 & .889 \\
\cline { 2 - 6 } & Pair 3 & $\mathrm{u}^{\mathrm{R}}(\mathrm{ST} \mid \mathrm{F}) \& \mathrm{u}^{\mathrm{R}}(\mathrm{ST} \mid \mathrm{M})$ & 20 & .144 & .543 \\
\hline
\end{tabular}

Source: Own processing

In Fig 3, we compared males and females by education ratios in unemployment to better explain differences between the European Union, Spain and Switzerland. On horizontal axis, data about females for suitable unemployment education ratio are presented (from left to right primary to secondary, primary to tertiary, secondary to tertiary), and on vertical axis are presented the same information but for men. This figure supports Table 4 and from it is obvious that unemployment gender inequality in Switzerland doesn't exist, not even in unemployment education ratios.
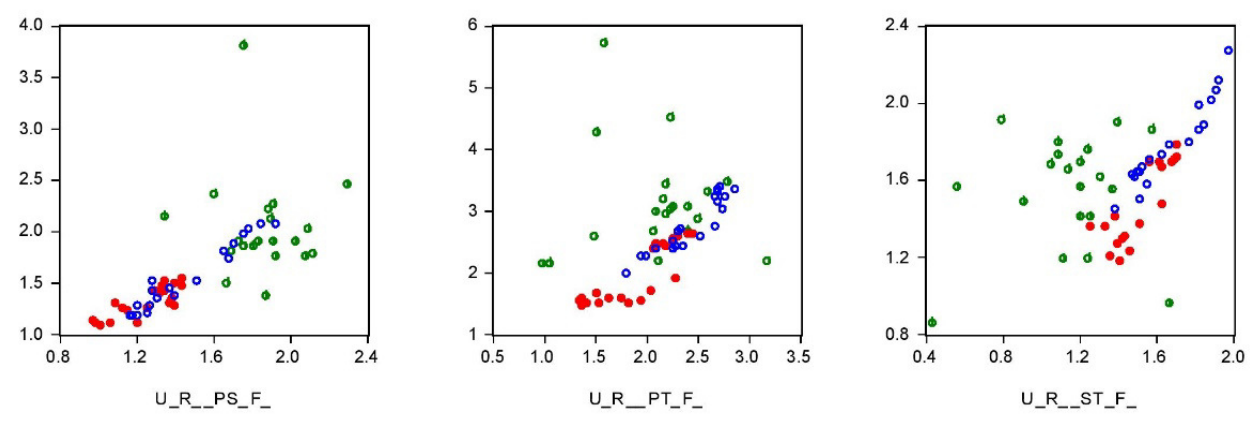

○ EuropeanUnion - Spain Switzerland

Fig. 3: Unemployment Education Attainment Ratios by Gender

Source: Own processing

Gender inequality in unemployment by education attainment is presented in Fig 4. From this figure, we can conclude that gender inequality by education attainment in unemployment doesn't exist. While in Spain and the European Union, unemployment gender inequality still exists between education attainments. In the European Union, gender inequality seems to be equal among all educational attainments in unemployment. 


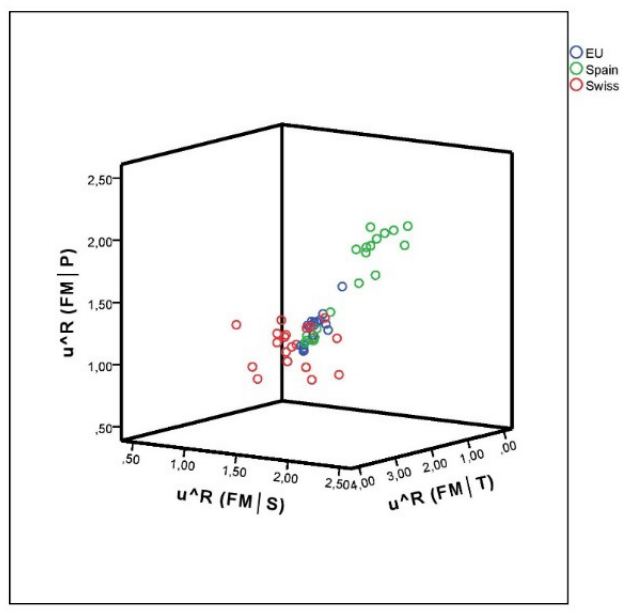

Fig. 4: Comparison of Gender Inequality in Unemployment by Education Attainments

Source: Own processing

\section{Results from Phillip-Perron Test with Break-Point}

Analysed series become stationary after adjustment to the first difference. With this step, we have obtained integrated series in accordance with Ng and Perron (1995). All analysed series were stationary at level 0.05 .

Even when structural breaks increased levels of education disparity in unemployment in Spain, they subsequently decreased its tendency. In time of break, the level of disparity shifted down. Structural break had the highest influence on the ratio of primary to tertiary education in unemployment in all three territories. In Spain, structural break shifted down differenced ratio by 0.830 , inequality level increased from 0.124 to 2.659 and trend changed from increase of 0.127 to decrease of 0.822 (Annex 1 ). In the European Union, structural break shifted down differenced ratio by 0.244 , inequality level increased from 0.012 to 0.36 and trend changed from increase of 0.050 to decrease of 0.049 (Annex 3). In Switzerland, structural break shifted up differenced ratio by 0.177 , inequality level changed from -0.767 to -1.336 and trend changed from increase of 0.517 to decrease of 0.049 (Annex 2). In conclusion, structural breaks were the highest in ratio of primary to tertiary education; this ratio was also the highest among other education attainment ratios in unemployment.

Structural break was also higher among women in primary to tertiary education attainment ratio in Spain and Switzerland (Annex 1 and 2). In the European Union, structural break had the highest influence on men in secondary to tertiary education attainment ratio. Here structural break shifted up differenced ratio of men by 0.416 , inequality level changed from -0.403 to -0.985 and slightly increased from 0.022 to 0.023 (Annex 3).

Structural break changed tendency of gender inequality by education attainments in Spain, Switzerland and the European Union, except of the gender inequality unemployment series of those with primary education. Structural break caused that series which had increasing tendency changed to decreasing, and decreasing changed to increasing tendency. Structural break had the highest influence in time when break occurred, on unemployment gender inequality among those with primary education in the European Union, on those with secondary education in Spain and on those with tertiary education in Switzerland. 
The breaks had the strongest impact on gender inequality of the unemployed with primary education in Switzerland, while they had the weakest impact on the European Union. Among those with secondary education, the breaks had the lowest impact on Spain, while they had a similar effect on Switzerland and the European Union. Inequality among those with tertiary education was most affected with random breaks in Switzerland, while this impact was lower by half in Spain.

Structural breaks had also a strong influence on the ratio between primary and secondary education in Switzerland, while this influence was weak in Spain. In Spain, the highest influence of breaks on the ratio between primary and secondary education was on the male population. This leads us to conclude that in Spain, in time of crisis, men unemployment rate is higher and approaches the women unemployment rate. In Switzerland, in time of crisis, those with primary education are more likely to lose their job than those with secondary and tertiary education.

Half-life estimators indicate the breaks had insignificant effect on the series trend and that their consequences disappeared very quickly. We can conclude that the breaks had a temporary rather than permanent effect on the series. In the European Union, the influence of structural break on secondary to tertiary education attainment ratio was more persistent and long lasting, but eventually would disappear.

\section{Conclusion}

The highest discrepancy among education attainment of the unemployed was between primary and tertiary education, while inequality among genders in unemployment was among those with tertiary education. Unemployment gender inequality among all educational attainments was decreasing in Spain and the European Union, while in Switzerland this inequality didn't existed. Discrepancy between primary and tertiary education was increasing in Spain and the European Union, while in Switzerland this discrepancy was steady over time. This could be explained by the fact that employers prefer highly educated employees. After comparing education discrepancies in unemployment by genders, we have discovered that genders were highly positively correlated in Spain and the European Union, while it was confirmed one more time that gender inequality in Switzerland doesn't exist between educational attainments in unemployment either.

Random economic disturbances increased levels of education disparity in unemployment but at the same time decreased its tendency in all three analysed territories. Structural breaks had the highest influence on primary to tertiary educational attainment in unemployment ratio in all three analysed territories. The highest influence of break on unemployment gender inequality in the time when break occurred was among those with primary education in the European Union, with secondary education in Spain and tertiary education in Switzerland.

Consequences of structural breaks quickly disappeared, and the influence of structural breaks was insignificant and only temporary. Inequality between genders today seems low and stationary, but female unemployment rate is still higher than male and further policies which would regulate gender inequality are needed in Spain, Switzerland and the European Union.

\section{Acknowledgment}

This paper was produced as a part of the SYLLF research abroad program, financed by the Nippon foundation, which we gratefully acknowledge.

\section{References}

1. Azmat, G., Güell, M. and Manning, A. (2004), Gender Gaps in Unemployment Rates in OECD Countries. London: Centre for Economic Performance.

2. Bakas, D. and Papapetrou, E. (2014), Unemployment by Gender: Evidence from EU Countries. 
International Advances in Economic Research, 20(1), pp. 103-111.

3. Belloc, M. and Tilli, R. (2013), Unemployment by gender and gender catching-up: Empirical evidence from the Italian regions. Papers in Regional Science, 92(3), pp. 481-494.

4. Dickey, D. A. and Fuller, W. A. (1979), Distribution of the Estimators for Autoregressive Time Series With a Unit Root. Journal of the American Statistical Association, 74(366), pp. 427-431.

5. European Commission (2011), Modernising higher education in the EU. [Online]

Available at: http://eurlex.europa.eu/LexUriServ/LexUriS erv.do?uri=COM:2011:0567:FIN:E $\mathrm{N}: \mathrm{PDF}$

[Accessed 6. 1. 2017].

6. Eurostat (2016), Eurostat. [Online] Available http://ec.europa.eu/eurostat/data /database

[Accessed 2901 2017].

7. Fallahi, F. and Rodriguez, G. (2015), Structural breaks and labor market disparities in the Canadian provinces. Journal of Economic Studies, 42(2), pp. 322342.

8. Fournier, M. C. and Mercier, C. S. (2009), Economics of Employment and Unemployment. New York: Nova Science Publishers, Inc.

9. Garcia-Cintado, A., Romero-Avila, D. and Usabiaga, C. (2015), Can the hysteresis hypothesis in Spanish regional unemployment be beaten? New evidence from unit root tests with breaks. Economic Modelling, Volume 47, pp. 244252.
10. Gokulsing, D. and TandrayenRagoobur, V. (2014), Gender, education and labour market: evidence from Mauritius. The International Journal of Sociology and Social Policy, 34(9/10), pp. 609-633.

11. Gozgor, G. (2013), Testing Unemployment Persistence in Central and Eastern European Countries. International Journal of Economics and Financial Issues, 3(3), pp. 694-700.

12. Chang, M. J. and Su, C. Y. (2014), Hysteresis versus natural rate in Taiwan's unemployment: Evidence from the educational attainment categories. Economic Modelling, Volume 43, pp. 293-304.

13. Koutentakis, F. (2015), Gender Unemployment Dynamics: Evidence from Ten Advanced Economies. Labour, 29(1), pp. 1531.

14. Marques, A. M., Lima, G. T. and Troster, V. (2017), Unemployment persistence in OECD countries after the Great Recession. Economic Modelling, Volume 64, pp. 105-116.

15. Muntigl, P., Weiss, G. and Wodak, R. (2000), European Union Discourses On Un/Employment: An Interdisciplinary Approach To Employment, Policy-Making And Organizational Change. Amsterdam: John Benjamins Publishing Company.

16. Newey, W. K. and West, K. D. (1994), Automatic Lag Selection in Covariance Matrix Estimation. The Review of Economic Studies, 61(4), pp. 631-653.

17. Ng, S. and Perron, P. (1995), Unit Root Tests in ARMA Models with Data-Dependent Methods for the Selection of the Truncation Lag. 
Journal of the American Statistical Association, 90(429), pp. 268-281.

18. Ng, S. and Perron, P. (1995), Unit Root Tests in ARMA Models with Data-Dependent Methods for the Selection of the Truncation Lag. Abingdon: Taylor \& Francis, Ltd..

19. Peiró, A., Belaire-Franch, J. and Gonzalo, M. T. (2012), Unemployment, cycle and gender. Journal of Macroeconomics, 34(4), pp. 1167-1175.

20. Perron, P. (1989), The Great Crash, the Oil Price Shock, and the Unit Root Hypothesis. Econometrica, 57(6), pp. 1361-1401.

21. Perron, P. (1997), Further evidence on breaking trend functions in macroeconomic variables. Journal of Econometrics, $80(2)$, pp. 355-385.

22. Phillips, P. C. B. and Perron, P. (1988), Testing for a Unit Root in Time Series Regression. Biometrika, 75(2), pp. 335-346.

23. Queneau, H. and Sen, A. (2007), Evidence Regarding Persistence in the Gender Unemployment Gap Based on the Ratio of Female to Male Unemployment Rate. Economics Bulletin, 5(23), pp. 110.

24. Queneau, H. and Sen, A. (2009a), Further Evidence on the Dynamics of Unemployment by Gender.
Economics Bulletin, 29(4), pp. 3162-3176.

25. Queneau, H. and Sen, A. (2009b), Regarding the unemployment gap by race and gender in the United States. Economics Bulletin, 29(4), pp. 2749-2757.

26. Riddell, W. C. and Song, X. (2011), The impact of education on unemployment incidence and reemployment success: Evidence from the U.S. labour market. Labour Economics, 18(4), pp. 453463.

27. Strahm, R. (2013), Switzerland: a dual track to low unemployment. [Online] Available at: http://www.elmmagazine.eu/artic les/what-are-they-doing-right-3cases [Accessed 3. 1. 2017].

28. Theodossiou, I. and Zangelidis, A. (2009), Should I stay or should I go? The effect of gender, education and unemployment on labour market transitions. Labour Economics, 16(5), pp. 566-577.

29. Van der Vleuten, A. (2013), The Price of Gender Equality: Member States and Governance in the European Union. Abingdon, Oxon: Ashgate Publishing Limited.

30. Venetis, I. A. and Salamaliki, P. K. (2015), Unit roots and trend breaks in the Greek labor market. Journal of Economic Studies, 42(4), pp. 641-658. 
Annex 1: Phillips-Perron Unit Root Test with break for the $u^{R}$ series of Spain

\begin{tabular}{|c|c|c|c|c|c|c|c|c|c|c|c|c|c|}
\hline Series & $T_{b}$ & $k^{*}$ & $\hat{\mu}$ & $\hat{\theta}$ & $\hat{\beta}$ & $\hat{\gamma}$ & $\hat{\delta}$ & $\hat{\alpha}$ & $\sigma^{2}$ & $R^{2}$ & $t$ & $p-$ value & $H L_{\rho}$ \\
\hline$u^{R}(P S \mid T)$ & 2007 & 5 & $\begin{array}{l}0.102 \\
(2.75) \\
\end{array}$ & $\begin{array}{l}0.241^{* * *} \\
(3.80)\end{array}$ & $\begin{array}{l}0.038 \\
(2.79) \\
\end{array}$ & $\begin{array}{l}-0.095^{* *} \\
(-5.24)\end{array}$ & $\begin{array}{l}-0.273^{* *} \\
(-6.03)\end{array}$ & $\begin{array}{l}-5.486^{* *} \\
(-6.62)\end{array}$ & 0.023 & 0.975 & -7.83 & $<0.01$ & 0.462 \\
\hline$u^{R}(P T \mid T)$ & 2011 & 5 & $\begin{array}{l}0.124^{* *} \\
(5.34) \\
\end{array}$ & $\begin{array}{l}2.535^{*} \\
(10.76) \\
\end{array}$ & $\begin{array}{l}0.127^{*} \\
(12.73)\end{array}$ & $\begin{array}{l}-0.949^{*} \\
(-14.55)\end{array}$ & $\begin{array}{l}-0.830^{* *} \\
(-8.22)\end{array}$ & $\begin{array}{l}-9.667^{*} \\
(-16.68)\end{array}$ & 0.024 & 0.996 & -18.40 & $<0.01$ & 0.321 \\
\hline$u^{R}(S T \mid T)$ & 2005 & 2 & $\begin{array}{l}-0.014 \\
(-0.30) \\
\end{array}$ & $\begin{array}{l}0.174^{*} \\
(3.77) \\
\end{array}$ & $\begin{array}{l}0.007 \\
(0.51) \\
\end{array}$ & $\begin{array}{l}-0.029^{* * *} \\
(-1.90)\end{array}$ & $\begin{array}{l}-0.279^{*} \\
(-4.43)\end{array}$ & $\begin{array}{l}-0.598^{* *} \\
(-2.66)\end{array}$ & 0.042 & 0.858 & -7.10 & $<0.01$ & 0.761 \\
\hline$u^{R}(P S \mid F)$ & 2009 & 0 & $\begin{array}{l}0.051 \\
(1.49)\end{array}$ & $\begin{array}{l}-0.215^{* *} \\
(-2.97)\end{array}$ & $\begin{array}{l}0.001 \\
(0.24)\end{array}$ & $\begin{array}{l}0.029^{* * *} \\
(2.11)\end{array}$ & $\begin{array}{l}0.143^{* * *} \\
(1.91)\end{array}$ & $\begin{array}{l}-0.451^{\text {*** }} \\
(-1.92)\end{array}$ & 0.053 & 0.486 & -6.17 & $<0.01$ & 1.156 \\
\hline$u^{R}(P T \mid F)$ & 2009 & 5 & $\begin{array}{l}0.195^{*} \\
(25.42) \\
\end{array}$ & $\begin{array}{l}-0.319^{*} \\
(-15.22) \\
\end{array}$ & $\begin{array}{l}0.075^{*} \\
(27.80) \\
\end{array}$ & $\begin{array}{l}-0.127^{*} \\
(-15.37)\end{array}$ & $\begin{array}{l}0.300^{*} \\
(17.56) \\
\end{array}$ & $\begin{array}{l}-4.040^{*} \\
(-24.88)\end{array}$ & 0.005 & 0.999 & -31.03 & $<0.01$ & 0.623 \\
\hline$u^{R}(S T \mid F)$ & 2009 & 4 & $\begin{array}{l}-0.034 \\
(-1.06)\end{array}$ & $\begin{array}{l}0.176 \\
(1.76)\end{array}$ & $\begin{array}{l}0.032^{*} \\
(4.79)\end{array}$ & $\begin{array}{l}-0.097^{*} \\
(-5.01)\end{array}$ & $\begin{array}{l}-0.226^{* *} \\
(-3.65)\end{array}$ & $\begin{array}{l}-3.483^{*} \\
(-5.24)\end{array}$ & 0.027 & 0.964 & -6.74 & $<0.01$ & 0.762 \\
\hline$u^{R}(P S \mid M)$ & 2003 & 0 & $\begin{array}{l}-0.029 \\
(-0.33) \\
\end{array}$ & $\begin{array}{l}0.004 \\
(0.05) \\
\end{array}$ & $\begin{array}{l}0.024 \\
(0.90) \\
\end{array}$ & $\begin{array}{l}-0.031 \\
(-1.14) \\
\end{array}$ & $\begin{array}{l}-0.241^{* *} \\
(-2.42) \\
\end{array}$ & $\begin{array}{l}-0.512^{* *} \\
(-2.66)\end{array}$ & 0.084 & 0.568 & -7.87 & $<0.01$ & 0.966 \\
\hline$u^{R}(P T \mid M)$ & 2007 & 4 & $\begin{array}{l}0.002 \\
(0.02) \\
\end{array}$ & $\begin{array}{l}1.076^{*} \\
(5.30) \\
\end{array}$ & $\begin{array}{l}0.016 \\
(0.51) \\
\end{array}$ & $\begin{array}{l}-0.156^{* *} \\
(-4.05)\end{array}$ & $\begin{array}{l}-0.725^{* *} \\
(-3.91) \\
\end{array}$ & $\begin{array}{c}-2.896^{*} \\
(-5.75) \\
\end{array}$ & 0.098 & 0.937 & -7.73 & $<0.01$ & 1.083 \\
\hline$u^{R}(S T \mid M)$ & 2007 & 3 & $\begin{array}{l}0.008 \\
(2.10) \\
\end{array}$ & \begin{tabular}{|l}
$0.464^{* *}$ \\
$(3.50)$ \\
\end{tabular} & $\begin{array}{l}-0.009 \\
(-0.56) \\
\end{array}$ & $\begin{array}{l}-0.046^{* * *} \\
(-1.95)\end{array}$ & $\begin{array}{l}-0.115 \\
(-0.93) \\
\end{array}$ & $\begin{array}{l}-1.791^{* *} \\
(-3.25)\end{array}$ & 0.065 & 0.835 & -5.07 & 0.0674 & 2.956 \\
\hline$u^{R}(F M \mid P)$ & 2007 & 1 & $\begin{array}{l}0.191^{* * *} \\
(2.09)\end{array}$ & \begin{tabular}{|c|}
$-0.498^{*}$ \\
$(-4.05)$ \\
\end{tabular} & $\begin{array}{l}-0.036^{* * *} \\
(-2.03)\end{array}$ & $\begin{array}{l}0.119^{*} \\
(3.96) \\
\end{array}$ & $\begin{array}{l}0.382^{* *} \\
(2.48) \\
\end{array}$ & $\begin{array}{l}-0.539^{* * *} \\
(-2.11)\end{array}$ & 0.094 & 0.793 & -6.01 & $<0.01$ & 0.895 \\
\hline$u^{R}(F M \mid S)$ & 2006 & 0 & $\begin{array}{l}0.265^{* * *} \\
(1.96) \\
\end{array}$ & $\begin{array}{c}-0.174 \\
(-1.02) \\
\end{array}$ & $\begin{array}{l}-0.064^{* *} \\
(-2.35) \\
\end{array}$ & $\begin{array}{l}0.117^{*} \\
(3.26) \\
\end{array}$ & $\begin{array}{l}0.472^{* *} \\
(2.38)\end{array}$ & $\begin{array}{l}-0.340 \\
(-1.51) \\
\end{array}$ & 0.160 & 0.517 & -5.93 & $<0.01$ & 1.668 \\
\hline$u^{R}(F M \mid T)$ & 2005 & 0 & $\begin{array}{l}0.408^{* *} \\
(2.98)\end{array}$ & $\begin{array}{l}0.167 \\
(1.08) \\
\end{array}$ & $\begin{array}{l}-0.107^{*} \\
(1.08)\end{array}$ & $\begin{array}{l}0.126^{*} \\
(3.36) \\
\end{array}$ & $\begin{array}{l}-0.103 \\
(-0.56)\end{array}$ & $\begin{array}{l}-0.552^{* *} \\
(-2.45)\end{array}$ & 0.148 & 0.561 & -6.90 & $<0.01$ & 0.863 \\
\hline
\end{tabular}

*Significant at level $0.01 ;{ }^{* *}$ Significant at level $0.05 ;{ }^{* * *}$ Significant at level 0.1

Numbers in parenthesis under the estimated coefficients are $t$-statistics for the null hypothesis.

Source: Own processing

Marina Fad'oš and Mária Bohdalová (2017), Journal of Human Resources Management Research, DOI: $10.5171 / 2017.117303$ 
Annex 2: Phillips-Perron Unit Root Test with break for the $u^{R}$ series of Switzerland

\begin{tabular}{|c|c|c|c|c|c|c|c|c|c|c|c|c|c|}
\hline Series & $T_{b}$ & $k^{*}$ & $\hat{\mu}$ & $\hat{\theta}$ & $\hat{\beta}$ & $\hat{\gamma}$ & $\hat{\delta}$ & $\hat{\alpha}$ & $\sigma^{2}$ & $R^{2}$ & $t$ & $p-$ value & $H L_{\rho}$ \\
\hline$u^{R}(P S \mid T)$ & 2001 & 0 & $\begin{array}{l}-0.871^{*} \\
(-3.16)\end{array}$ & $\begin{array}{l}-0.434^{* * *} \\
(-2.18)\end{array}$ & $\begin{array}{l}0.366^{* *} \\
(2.87)\end{array}$ & $\begin{array}{l}-0.345^{* *} \\
(-2.69)\end{array}$ & $\begin{array}{l}0.505^{* *} \\
(2.44)\end{array}$ & $\begin{array}{l}-0.680^{*} \\
(-4.98)\end{array}$ & 0.180 & 0.770 & -12.30 & $<0.01$ & 0.608 \\
\hline$u^{R}(P T \mid T)$ & 2006 & 5 & $\begin{array}{l}-0.767^{* *} \\
(-5.85)\end{array}$ & $\begin{array}{l}-0.569^{* *} \\
(-7.02)\end{array}$ & $\begin{array}{l}0.517^{* *} \\
(8.39)\end{array}$ & $\begin{array}{l}-0.566^{* *} \\
(-9.17)\end{array}$ & $\begin{array}{l}0.177 \\
(2.32)\end{array}$ & $\begin{array}{l}-3.112^{*} \\
(-16.02)\end{array}$ & 0.029 & 0.998 & -21.17 & $<0.01$ & 0.927 \\
\hline$u^{R}(S T \mid T)$ & 2003 & 0 & $\begin{array}{l}0.631^{*} \\
(3.42)\end{array}$ & $\begin{array}{l}0.385^{* * *} \\
(2.11)\end{array}$ & $\begin{array}{l}-0.172^{*} \\
(-3.08)\end{array}$ & $\begin{array}{l}0.152^{* *} \\
(2.62)\end{array}$ & $\begin{array}{l}-0.162 \\
(-0.76)\end{array}$ & $\begin{array}{l}-0.179 \\
(-1.01)\end{array}$ & 0.176 & 0.533 & -6.64 & $<0.01$ & 3.514 \\
\hline$u^{R}(P S \mid F)$ & 2005 & 0 & $\begin{array}{l}-0.434^{* *} \\
(-2.68)\end{array}$ & $\begin{array}{l}-0.395^{* * *} \\
(-1.99)\end{array}$ & $\begin{array}{l}0.090^{* *} \\
(2.50)\end{array}$ & $\begin{array}{l}-0.061 \\
(-1.45)\end{array}$ & $\begin{array}{l}0.501^{* * *} \\
(2.13)\end{array}$ & $\begin{array}{l}-0.614^{*} \\
(-3.70)\end{array}$ & 0.192 & 0.657 & -9.74 & $<0.01$ & 0.728 \\
\hline$u^{R}(P T \mid F)$ & 2008 & 2 & $\begin{array}{l}0.162 \\
(1.16)\end{array}$ & $\begin{array}{l}-1.001^{*} \\
(-5.13)\end{array}$ & $\begin{array}{l}0.031 \\
(1.15)\end{array}$ & $\begin{array}{l}0.068 \\
(1.69)\end{array}$ & $\begin{array}{l}0.929^{*} \\
(4.45)\end{array}$ & $\begin{array}{l}-1.632^{*} \\
(-7.10)\end{array}$ & 0.153 & 0.899 & -11.46 & $<0.01$ & 1.511 \\
\hline$u^{R}(S T \mid F)$ & 2001 & 0 & $\begin{array}{l}-0.746^{* * *} \\
(-1.80)\end{array}$ & $\begin{array}{l}-0.632^{* *} \\
(-2.90)\end{array}$ & $\begin{array}{l}0.485^{* *} \\
(2.67)\end{array}$ & $\begin{array}{l}-0.493^{* *} \\
(-2.72)\end{array}$ & $\begin{array}{l}-0.359 \\
(-1.52)\end{array}$ & $\begin{array}{l}-0.343^{* * *} \\
(-1.94)\end{array}$ & 0.179 & 0.671 & -7.57 & $<0.01$ & 1.650 \\
\hline$u^{R}(P S \mid M)$ & 2010 & 4 & $\begin{array}{l}-0.640^{*} \\
(-8.31)\end{array}$ & $\begin{array}{l}0.112 \\
(0.83)\end{array}$ & $\begin{array}{l}0.070^{* *} \\
(4.31)\end{array}$ & $\begin{array}{l}-0.054 \\
(-1.56)\end{array}$ & $\begin{array}{l}-0.388^{* *} \\
(-2.92)\end{array}$ & $\begin{array}{l}-2.295^{*} \\
(-10.34)\end{array}$ & 0.089 & 0.990 & -14.85 & $<0.01$ & 2.681 \\
\hline$u^{R}(P T \mid M)$ & 2010 & 5 & $\begin{array}{l}-1.681^{* * *} \\
(-3.91)\end{array}$ & $\begin{array}{l}0.237 \\
(0.89)\end{array}$ & $\begin{array}{l}0.289^{* * *} \\
(3.50)\end{array}$ & $\begin{array}{l}-0.472^{* *} \\
(-4.67)\end{array}$ & $\begin{array}{l}-0.631 \\
(-2.88)\end{array}$ & $\begin{array}{l}-4.323^{* *} \\
(-6.28)\end{array}$ & 0.147 & 0.978 & -7.73 & $<0.01$ & 0.577 \\
\hline$u^{R}(S T \mid M)$ & 2003 & 2 & $\begin{array}{l}0.949^{*} \\
(3.53)\end{array}$ & $\begin{array}{l}0.824^{*} \\
(4.77) \\
\end{array}$ & $\begin{array}{l}-0.475^{*} \\
(-4.01) \\
\end{array}$ & $\begin{array}{l}0.432^{*} \\
(3.76)\end{array}$ & $\begin{array}{l}-0.677^{*} \\
(-4.03) \\
\end{array}$ & $\begin{array}{l}-1.397^{*} \\
(-4.87) \\
\end{array}$ & 0.099 & 0.876 & -8.36 & $<0.01$ & 0.750 \\
\hline$u^{R}(F M \mid P)$ & 2001 & 0 & $\begin{array}{l}0.606^{* *} \\
(2.98)\end{array}$ & $\begin{array}{l}0.300^{* * *} \\
(2.03)\end{array}$ & $\begin{array}{l}-0.286^{* *} \\
(-3.04)\end{array}$ & $\begin{array}{l}0.280^{* *} \\
(2.96)\end{array}$ & $\begin{array}{l}0.139 \\
(0.90) \\
\end{array}$ & $\begin{array}{c}-0.618^{*} \\
(-4.20) \\
\end{array}$ & 0.133 & 0.712 & -10.99 & $<0.01$ & 0.720 \\
\hline$u^{R}(F M \mid S)$ & 2009 & 4 & $\begin{array}{l}-0.354^{* *} \\
(-4.49)\end{array}$ & $\begin{array}{l}-0.186 \\
(-1.90) \\
\end{array}$ & $\begin{array}{l}0.056^{* *} \\
(3.12)\end{array}$ & $\begin{array}{l}-0.044 \\
(-1.88) \\
\end{array}$ & $\begin{array}{l}-0.156 \\
(-1.63) \\
\end{array}$ & $\begin{array}{c}-2.237^{*} \\
(-8.81) \\
\end{array}$ & 0.067 & 0.989 & -12.75 & $<0.01$ & 3.259 \\
\hline$u^{R}(F M \mid T)$ & 2010 & 4 & $\begin{array}{l}-1.281^{*} \\
(-13.76) \\
\end{array}$ & $\begin{array}{l}0.064 \\
(0.41) \\
\end{array}$ & $\begin{array}{l}0.176^{*} \\
(9.61) \\
\end{array}$ & $\begin{array}{c}-0.270^{*} \\
(-7.05) \\
\end{array}$ & $\begin{array}{l}-0.232 \\
(-1.53) \\
\end{array}$ & $\begin{array}{l}-2.606^{*} \\
(-17.25) \\
\end{array}$ & 0.104 & 0.994 & -23.87 & $<0.01$ & 1.463 \\
\hline
\end{tabular}

*Significant at level $0.01 ;{ }^{* *}$ Significant at level $0.05 ;{ }^{* * *}$ Significant at level 0.1

Numbers in parenthesis under the estimated coefficients are $t$-statistics for the null hypothesis.

Source: Own processing 
Annex 3: Phillips-Perron Unit Root Test with break for the $u^{R}$ series of European Union

\begin{tabular}{|c|c|c|c|c|c|c|c|c|c|c|c|c|c|}
\hline Series & $T_{b}$ & $k^{*}$ & $\hat{\mu}$ & $\hat{\theta}$ & $\hat{\beta}$ & $\hat{\gamma}$ & $\hat{\delta}$ & $\hat{\alpha}$ & $\sigma^{2}$ & $R^{2}$ & $t$ & $p-$ value & $H L_{\rho}$ \\
\hline$u^{R}(P S \mid T)$ & 2007 & 5 & $\begin{array}{l}-0.262^{* *} \\
(-6.85) \\
\end{array}$ & $\begin{array}{l}0.458^{* *} \\
(7.75) \\
\end{array}$ & $\begin{array}{l}0.099^{* *} \\
(7.71) \\
\end{array}$ & $\begin{array}{l}-0.141^{* *} \\
(-8.79) \\
\end{array}$ & $\begin{array}{l}-0.260^{* *} \\
(-6.53) \\
\end{array}$ & \begin{tabular}{|l}
$-3.978^{* *}$ \\
$(-8.16)$ \\
\end{tabular} & 0.018 & 0.984 & -10.21 & $<0.01$ & 0.635 \\
\hline$u^{R}(P T \mid T)$ & 2007 & 5 & $\begin{array}{l}0.012 \\
(0.25)\end{array}$ & $\begin{array}{l}0.348^{* *} \\
(6.04)\end{array}$ & $\begin{array}{l}0.050^{* * *} \\
(3.02)\end{array}$ & $\begin{array}{l}-0.099^{* *} \\
(-6.36)\end{array}$ & $\begin{array}{l}-0.244^{* *} \\
(-5.95)\end{array}$ & $\begin{array}{l}-3.443^{*} \\
(-10.79)\end{array}$ & 0.017 & 0.994 & -13.92 & $<0.01$ & 0.776 \\
\hline$u^{R}(S T \mid T)$ & 2001 & 1 & $\begin{array}{l}0.089 \\
(0.88)\end{array}$ & $\begin{array}{l}-0.406^{*} \\
(-7.87)\end{array}$ & $\begin{array}{l}0.122 \\
(1.78)\end{array}$ & $\begin{array}{l}-0.119 \\
(-1.73)\end{array}$ & $\begin{array}{l}0.265^{*} \\
(5.29)\end{array}$ & $\begin{array}{l}-0.060 \\
(-0.68) \\
\end{array}$ & 0.023 & 0.980 & -11.97 & $<0.01$ & 11.202 \\
\hline$u^{R}(P S \mid F)$ & 2007 & 5 & $\begin{array}{l}-0.111^{* * *} \\
(-4.26)\end{array}$ & $\begin{array}{l}0.367^{* *} \\
(6.81)\end{array}$ & $\begin{array}{l}0.047^{* *} \\
(5.09)\end{array}$ & $\begin{array}{l}-0.072^{* *} \\
(-5.95)\end{array}$ & $\begin{array}{l}-0.186^{* *} \\
(-5.58)\end{array}$ & $\begin{array}{l}-4.083^{* *} \\
(-7.92) \\
\end{array}$ & 0.012 & 0.988 & -9.86 & $<0.01$ & 0.616 \\
\hline$u^{R}(P T \mid F)$ & 2013 & 5 & $\begin{array}{l}0.286^{* *} \\
(7.39) \\
\end{array}$ & $\begin{array}{l}-0.386^{* *} \\
(-4.82)\end{array}$ & $\begin{array}{l}-0.009^{* *} \\
(-5.05)\end{array}$ & $\begin{array}{l}0.114^{* *} \\
(4.67)\end{array}$ & $\begin{array}{l}0.129 \\
(2.73) \\
\end{array}$ & \begin{tabular}{|l}
$-2.833^{* *}$ \\
$(-4.91)$ \\
\end{tabular} & 0.014 & 0.993 & -6.65 & $<0.01$ & 1.144 \\
\hline$u^{R}(S T \mid F)$ & 2009 & 5 & $\begin{array}{l}1.166^{*} \\
(10.06)\end{array}$ & $\begin{array}{l}-0.080^{* *} \\
(-5.99) \\
\end{array}$ & $\begin{array}{l}-0.246^{*} \\
(-10.81) \\
\end{array}$ & $\begin{array}{l}0.263^{*} \\
(11.13) \\
\end{array}$ & $\begin{array}{l}0.289^{* *} \\
(9.25)\end{array}$ & \begin{tabular}{|l}
$-6.031^{*}$ \\
$(-9.96)$ \\
\end{tabular} & 0.005 & 0.996 & -11.61 & $<0.01$ & 0.429 \\
\hline$u^{R}(P S \mid M)$ & 2008 & 2 & $\begin{array}{l}-0.252^{*} \\
(-9.83) \\
\end{array}$ & $\begin{array}{l}-0.021 \\
(-0.54) \\
\end{array}$ & $\begin{array}{l}0.056^{*} \\
(11.48) \\
\end{array}$ & $\begin{array}{l}-0.067^{*} \\
(-7.75) \\
\end{array}$ & $\begin{array}{l}0.217^{*} \\
(6.51)\end{array}$ & \begin{tabular}{|l}
$-0.924^{*}$ \\
$(-4.60)$ \\
\end{tabular} & 0.024 & 0.970 & -9.58 & $<0.01$ & 0.269 \\
\hline$u^{R}(P T \mid M)$ & 2006 & 2 & $\begin{array}{l}0.449^{* *} \\
(2.71)\end{array}$ & $\begin{array}{l}0.682^{*} \\
(3.61) \\
\end{array}$ & $\begin{array}{l}-0.106^{* *} \\
(2.65)\end{array}$ & $\begin{array}{l}0.063 \\
(1.61) \\
\end{array}$ & $\begin{array}{l}-0.321 \\
(-1.78)\end{array}$ & $\begin{array}{l}-1.484^{* *} \\
(-3.16) \\
\end{array}$ & 0.123 & 0.691 & -5.28 & 0.0379 & 0.955 \\
\hline$u^{R}(S T \mid M)$ & 2001 & 0 & $\begin{array}{l}-0.403^{*} \\
(-9.71) \\
\end{array}$ & $\begin{array}{l}-0.582^{*} \\
(-18.56) \\
\end{array}$ & $\begin{array}{l}0.289^{*} \\
(14.79) \\
\end{array}$ & $\begin{array}{l}-0.282^{*} \\
(-14.34) \\
\end{array}$ & $\begin{array}{l}0.416^{*} \\
(9.14) \\
\end{array}$ & \begin{tabular}{|l}
$-0.245^{*}$ \\
$(-3.29)$ \\
\end{tabular} & 0.027 & 0.974 & -16.72 & $<0.01$ & 2.466 \\
\hline$u^{R}(F M \mid P)$ & 2007 & 1 & $\begin{array}{c}-0.148^{*} \\
(-7.66) \\
\end{array}$ & $\begin{array}{l}-0.199^{*} \\
(-7.41)\end{array}$ & $\begin{array}{l}0.022^{*} \\
(5.75) \\
\end{array}$ & $\begin{array}{l}0.001 \\
(0.18) \\
\end{array}$ & $\begin{array}{l}0.162^{*} \\
(5.25) \\
\end{array}$ & $\begin{array}{l}-0.512^{*} \\
(-5.95) \\
\end{array}$ & 0.024 & 0.934 & -17.57 & $<0.01$ & 0.966 \\
\hline$u^{R}(F M \mid S)$ & 2001 & 0 & $\begin{array}{l}0.494^{*} \\
(4.07)\end{array}$ & $\begin{array}{l}0.212^{* *} \\
(2.56)\end{array}$ & $\begin{array}{c}-0.254^{*} \\
(-4.47)\end{array}$ & $\begin{array}{l}0.258^{*} \\
(4.51)\end{array}$ & $\begin{array}{l}-0.067 \\
(-0.79)\end{array}$ & $\begin{array}{l}-0.665^{*} \\
(-3.65)\end{array}$ & 0.074 & 0.676 & -9.15 & $<0.01$ & 0.634 \\
\hline$u^{R}(F M \mid T)$ & 2001 & 0 & $\begin{array}{l}0.635^{*} \\
(5.26)\end{array}$ & $\begin{array}{l}0.146^{* * *} \\
(1.81)\end{array}$ & $\begin{array}{c}-0.294^{*} \\
(-5.34)\end{array}$ & $\begin{array}{l}0.303^{*} \\
(5.44)\end{array}$ & $\begin{array}{l}0.041 \\
(0.49)\end{array}$ & $\begin{array}{l}-0.658^{*} \\
(-4.06)\end{array}$ & 0.073 & 0.747 & -10.24 & $<0.01$ & 0.646 \\
\hline
\end{tabular}

*Significant at level $0.01 ;{ }^{* *}$ Significant at level $0.05 ;{ }^{* * *}$ Significant at level 0.1

Numbers in parenthesis under the estimated coefficients are $t$-statistics for the null hypothesis.

Source: Own processing

Marina Fad'oš and Mária Bohdalová (2017), Journal of Human Resources Management Research, DOI: $10.5171 / 2017.117303$ 